\title{
The Mediaeval Background of Self-Identification in Relation to the Filioque Controversy
}

\author{
SzABOlCS ANDRÁs*
}

The study at hand is not focused on the mediaeval theological history of the Filioque controversy but aims to examine how the mediaeval (particularly the Palamite) doctrine of procession has become an ideological element of identity in presentday interpretation. Based on the assumption that religious elements have become part of the political identity primarily in south-eastern Europe, the present paper makes reference first of all to representatives of Orthodox theology, without seeking to criticize, however, the Orthodox standpoint on the Filioque. Provided that it can be demonstrated that contemporary authors make use of mediaeval sources not merely theologically but also ideologically, then we can ascertain that the mediaeval Filioque controversy influences the present-day interpretation of self-identity.

Keywords: Filioque, Palamite theology, Late Middle Ages, Identification, Nation, Society.

\section{Preliminary Considerations and the Research Thesis}

The Filioque controversy is one of the major dogmatic points of contention dividing Christianity, separating the Orthodox and Western (Catholic/ Protestant) believers. ${ }^{1}$ This issue stretches like a red line, so to speak, across the pages of the history of Christianity, from the early church to the present days therefore, finding potential solutions in this respect is a particularly important task to be taken on by the ecumenical movement. ${ }^{2}$ It is a widespread phenomenon that the Filioque comes under analysis exclusively as a theological issue. I take the view that this is a restrictive position that renders both an extensive debate of the question and outlining the possible solutions more difficult.

\footnotetext{
*Szabolcs András, Lecturer, Ph.D., Catholic Dogmatic Theology, Babeș-Bolyai University, Department of Didactical Theology, Cluj-Napoca, Str. Iuliu Maniu, no. 5, Cluj-Napoca, 400095, Cluj county, Romania, andras.szabolcs@ubbcluj.ro.

${ }^{1}$ Regarding the Filioque issue, Siecienski's monograph is the most exhaustive: Edward A. Siecienski, The Filioque: History of a Doctrinal Controversy (Oxford: Oxford University Press, 2010).

${ }^{2}$ The last significant ecumenical document in our topic was issued by the North American Orthodox and Catholic bishops in 2003: The Filioque: A Church Dividing Issue? An Agreed Statement; North American Orthodox-Catholic Theological Consultation, see: http://www. usccb.org/beliefs-and-teachings/ecumenical-and-interreligious/ecumenical/orthodox/filioque-church-dividing-issue-english.cfm, accessed June 27, 2021.
} 
From my observation, the Filioque clause is a complex theological, historical, political, and cultural topic whose relevance has until now far exceeded the dogmatic context: it has become an element of self-identification. ${ }^{3}$ Those rejecting the Filioque clause think of themselves as Orthodox not just in religious but also in cultural-political terms, whereas individuals accepting the dogma are heterodox, who differ not only from a religious perspective but in other ways too.

The transformation of the dogmatic thesis into an identity element is the outcome of a historical process in the course of which theological criteria do not necessarily play a key role. ${ }^{4}$ Politics and exercise of power have the capability to turn divisive theological topics into a symbol whose integration into public discourse will enable the distinction of the foreign element on all levels of society. This paradigm does not feature the Filioque primarily as the origin of the Holy Spirit but in terms of social attitude, distinction. ${ }^{5}$ Its use can be defensive in nature (preservation of the existing social structure) or conflictual (exclusion of foreign elements).

Both Orthodox and Catholic theology have a quite stereotyped way of thinking about the Filioque clause, the latter one even categorizing it as something belonging to the past, not attaching any current importance to it. According to the simplistic (model) description, the foundations of the Filioque can be traced back to the difference between the Cappadocian and the Augustine perspectives, thereafter becoming one of the major drivers of the 1054 schism, while today it can be defined as a formal difference present in the text of the Creed. In this context, the Middle Ages sees the radical-

\footnotetext{
${ }^{3}$ Rogers Brubaker outlined four complementary ways to analyse the interferences between religion and politics: religious nationalism, religion as the explanation of nationalism, the interconnection of religion and politics, and religious nationalism as a separate ideology. In my view, Brubaker's proposal is a good starting point in contemporary Filioque analysis. Rogers Brubaker, "Religion and Nationalism: Four Approaches", Nations and Nationalism, 18. no. 1 (2012): 2-20.

${ }^{4}$ In his landmark study, A. H. M. Jones pointed out that among the early mediaeval heresies and religious divisions, those have become distinguishing features of ideology that had a social or "ethnic" element associated with them. Such was the case of the Donatists and Copts in North Africa, who revolted against the élite of European descent. In certain scenarios, the formation of independent statehood was accompanied by the development of peculiar religious organizations such as in the case of Armenians and Aryan Germans. A. H. M. Jones, "Were Ancient Heresies National or Social Movements in Disguise?," The Journal of Theological Studies 10, no. 2 (1959): 280-98.

${ }^{5}$ We can find some examples regarding the Filioque as a delimitation element: Agapit Popovici, "Ecumenismul încotro? O nouă viziune ortodoxă asupra ecumenismului sincretist," see: https://www.resurse-ortodoxe.ro/text/agapit-popovici-ecumenismul-incotro, accessed June 27, 2021. Another example: Alexandros Kalomiros, Impotriva falsei uniri bisericești (Bucharest: Cristiana, 2005), 42.
} 
ization of the conflict: Photios in the East and the Frankish Empire in the West utilized it as a means to pursue their own interests. ${ }^{6}$ Contemporary Orthodox theology looks into the question from a patristic perspective, seeking to demonstrate that the Catholic position is not compatible with the teaching of the Church Fathers. On the other hand, Western theology sees the Filioque as a matter of knowing God and places the research problem in the context of immanent and economic trinitology. Although both parties willingly draw on the prominent mediaeval theologian, Saint Maximus the Confessor, this has not yet contributed to the significant convergence of views. ${ }^{7}$

The introductory part so far already confronts us with a paradoxical situation: in relation to the Filioque, Orthodox and the Catholic theology are well aware of the role played by mediaeval theological and historical elements, yet they do not attach great importance to them in the current discussion of the issue. A reconsideration of the Middle Ages appears to be necessary if we are to gain an improved understanding of the manifold connotations of the Filioque. In what follows, we will attempt to investigate certain mediaeval theological and political aspects that ultimately facilitated the enhanced identification role of the Filioque. In this connection, I will be paying particular attention to understanding the Palamite theology of the Late Middle Ages and the Council of Florence as factors that still determine both the Orthodox and the Western identity and position.

\section{Revisiting the Late Mediaeval turning Point: Palamas's Significance and the Outcome of the Council of Florence}

There is no doubt that the political rift between the Greek East and the Latin West developed around the eighth and ninth centuries, at the same time when the Frankish Empire became firmly established. However, there were also some ecclesiastical components of this political rift such as Patriarch Photios's activities (notwithstanding how we describe his work). Yet, these events were first of all political in nature, failing to have any lasting theology-forming influence, which is proven by the fact that following the death of Charlemagne and Photios, political tension persisted while church unity re-

\footnotetext{
${ }^{6}$ Peter Gemeinhardt, "The Dynamics of Mutual Condemnations in the Filioque Controversy," Ephemerides Theologicae Lovanienses 91, no. 2 (2015): 201-22.

${ }^{7}$ Lossky insisted that Filioque should be approached as a patristic subject because the right answer can be found only in the Church Fathers' work. Vladimir Lossky, Orthodox Theology: An Introduction, trans. Ian and Ihita Kesarcodi-Watson (Crestwood: St. Vladimir's Seminary Press, 1978), 45-50.
} 
mained apparently untouched. ${ }^{8}$ But an onerous inheritance was left behind by this period after all, i.e., the double pressure put on Byzantium: on the one hand, the Muslim expansion from the east (Arabs at the time and then the Turks) and, on the other, the strengthening of Catholic empires from the west (the Holy Roman Empire following the Frankish one). The primary target of the pressure exerted by the Holy Roman Empire was not Byzantium but Rome, which they endeavoured to put at the service of imperial politics. ${ }^{9}$ Theology was a means in the hands of a political actor for the ideological justification of his mission's divine origin (this was highly visible before in the Frankish court as well, where the adroit Alkuin's activities contributed to the consolidation of Charlemagne's power). Against this backdrop, 1054 was merely a symbolic date and not a game-changing milestone in and of itself. What it meant in fact was that Byzantium has now permanently lost its final grip on Rome (and Italy). Considering our topic, this symbolic turning point occurred as early as 1014, when Rome too - under German pressure - began using the Niceno-Constantinopolitan Creed with the Filioque addition. ${ }^{10}$

The significance of the year 1014 has completely vanished by now in this respect from Catholic mentality, but for Orthodoxy it has definitively reaffirmed the conviction that the Latin Church is ready to even deviate from conciliar practice, if need be, in pursuing their own ambitions (reinforcing papal primacy) and in order to serve political power. The aftermath of the event can be perceived in the way Western rhetoric changes in the period of 1014-1054: it is no longer the Latins completing the text of the Creed but the Greeks leaving the confession of the role of the Son out of it. ${ }^{11}$ Accordingly, the form of the Creed became an element of identification in the year 1054: one could distinguish between true believers and misbelievers (i.e. ortho-dox - hetero-dox) based on the version of the Creed they used. Therefore, the period of 1014-1054 marks the start of formal separation and the initial phase in the development of regional identity. This put an end to the political-ecclesiastical processes started in the eighth and ninth

\footnotetext{
${ }^{8}$ Jean Meyendorff, Initiation a la Theologie Byzantine. L'histoire et la doctrine (Paris: Cerf, 1975), 81-85.

9 According to Stăniloae, German cultural supremacy endangered Orthodoxy in the Modern Ages too. Dumitru Stăniloae, "Biserica Ortodoxă a Transilvaniei," Gândirea 22, no. 5 (1943): 241-48.

${ }^{10}$ The document of the Pontifical Council states that before 1014 the Filioque was already in general use in the Catholic Church, this year being only the official beginning of the insertion. "The Greek and the Latin Traditions regarding the Procession of the Holy Spirit," Information Service of the Secretariat of The Pontifical Council for Promoting Christian Unity 89, no. 2-3 (1995): 90.

${ }^{11}$ Siecienski, The Filioque, 114.
} 
centuries, but the effective theological identity formation - that would later have repercussions on the socio-political processes - was just about to start.

I believe that the series of events taking place in the eleventh century may be regarded as the beginning and not the end result of the development of dogmatic identity formation because it is posterity that can assess the relevance of the above-mentioned events. ${ }^{12}$ At the time, it was not yet clear for the people of the era that the clock had been reset in Orthodox-Catholic relations, which may also be indicated by the position of the Catholic Church, which as late as at the 1274 Second Council of Lyon was still very much convinced that it could control Greek Christianity. ${ }^{13}$ By that time, however, the late medieval flourishing of Byzantine theology was in its full swing, which can be clearly linked to Palamism. To be a little more specific, Orthodox theology reacted relatively slowly to the political events of the $11^{\text {th }}$ century, but once it had blazed its own trail, such profound changes and identity formation were produced that set the framework for the self-definition of Orthodoxy to this day, together with its position taken on the Filioque controversy.

The difference between the changes that occurred in the eighth to eleventh and the ones experienced in the thirteenth to fifteenth centuries lies in the fact that the former had an external, political cause, took place at the upper levels of the hierarchy, and did not reach broad sectors of society, neither the lower clergy nor the monastic orders, whereas the latter started as an internal renewal. We might even refer to it as an Orthodox reformation, taking note that it did not trigger an institutional schism though certain fault lines did come about within the church. This renewal termed Palamism started off from among the monastic orders, having a large influence at a practical level on all scales of the hierarchy, which is exactly why it would enjoy widespread support in the future unfolding of conflicts. ${ }^{14}$ When other pressures

\footnotetext{
${ }^{12}$ What I call dogmatic identification is the process of reinterpretation of a religious doctrine by political rhetoric, which later can be used to stigmatize an ideological foe. This process needs an identification dogma, a controversial doctrine, e.g. papal primacy or Filioque, which was a theological issue but gradually became a political symbol.

${ }^{13}$ As postulated by Lossky, the errancy of St Thomas Aquinas and of the 1274 Council can be traced back to the fact that they interpreted causality based upon the Aristotelian philosophy, causality in that system being understood as an external factor, which is why they could not apply it to the person of the Father. On the contrary, based on the monarchy, causality is connected to the person of the Father and the immanent life of God in Cappadocian and Greek theology, which makes the Father be the sole cause of the Son and the Holy Spirit. Vladimir Lossky, Théologie Dogmatique (Paris: Cerf, 2012), 55-57.

${ }^{14}$ Monasticism, especially Mount Athos, is suspicious of ecumenism even today. Aurel Pavel and Ciprian Iulian Toroczkai, Adevăratul și falsul ecumenism (Sibiu: Andreiana, 2010), 209.
} 
coming from outside Orthodoxy presented themselves, many would identify Palamism with Orthodoxy, without even having its theological message come across to them. Eventually, Palamism also turned into a symbol of Orthodoxy despite the paradoxical situation that the position of the Orthodox Church on this theological trend is yet to be fully clarified. ${ }^{15}$ Nevertheless, this is the point of departure for present-day neo-Palamites in their radical rejection of the Filioque and stepping forward as defenders of Orthodox identity.

I do not propose to dwell at length on the analysis of Palamite theology since the focus of my interest is not so much its theological content but rather its socio-political effects. For reasons of clarity, it is worth noting that the doctrine of uncreated energies and of the Jesus Prayer is not Saint Gregory Palamas's innovation, as it goes back to a long history traceable in the works of Byzantine authors. Most probably, he borrowed the essential elements from Saint Gregory of Cyprus, who speaks about the procession of the Holy Spirit as the emanation of light, also using the phrase of resting on the Son. ${ }^{16}$ This theory has always had a dual orientation, serving as the theological foundation of experiential prayer within Orthodox theology on the one hand while attempting to express the Orthodox position in the debate with Western theology on the other. In the latter case, the challenge was to preserve the incomprehensible nature of divine immanence and maintain the direct relationship between God and man at the same time. Given that in the interpretation of Orthodoxy the Filioque doctrine goes far beyond the scope of apophatic theology, thus suggesting that the human intellect can form an image of the inner divine life, it was unacceptable to him. The roots of this position certainly go back to Saint Gregory of Nazianzus. ${ }^{17}$ This rejection automatically brings up the question, even the accusation, that for the sake of maintaining the apophatic theology Orthodoxy calls into question the possibility of the God-man relationship, which may give rise to further major theological problems. A possible answer came from the world of mysticism, offering a basis that would develop into Palamism over time, which would then, however, bring about increased controversies within Orthodoxy. ${ }^{18}$

\footnotetext{
${ }^{15}$ Zizioulas considers that the thesis of uncreated energies is a good answer for Rahner's axiom, but only Cappadocians represent the entire Orthodox position. John D. Zizioulas, Communion and Otherness. Further Studies in Personhood and the Church (London-New York: T\&T Clark, 2009), 203.

${ }^{16}$ Jean Meyendorff, Introduction a l'étude de Grégoire Palamas (Paris: Aux Éditions du Seuil, 1959), 25-43.

${ }^{17}$ Gregorius Nazianzensis, Orationes XXXI Theologia Quinta, PG 36:148.

18 The contrast between the local and universal church is a persistent problem in Orthodoxy. Pantelis Kalaitzidis, "Holy Lands and Sacred Nations," Concilium 1 (2015): 120.
} 
The debate unfolding around the Jesus prayer is the prefigurement of present-day disagreements persisting about charismatic practices of faith. There have been many to criticize this religious practice and especially the role played by the monks of Mount Athos in its promotion. The symbolic figure of the opposition camp was Barlaam of Calabria, who himself has become a symbol, and, even more importantly, a symbol-forming figure. It appeared to Barlaam that the monastic way of praying, tending towards mysticism, was crossing the boundaries of apophaticism - consequently, the knowledge of God was the primary focus of the controversy unfolding around him. A monk of Mount Athos himself, Saint Gregory Palamas came forward to refute Barlaam's allegations, and it was in this context that he developed his teaching on uncreated energies, also including his Filioque critique as a side issue. ${ }^{19}$ It is important to keep in mind that the Western viewpoint on the procession of the Holy Spirit was presented here merely as a side issue, as Barlaam had never professed it himself - in fact, he took a stand against it, even when formally joining the Catholic Church.

Considering his activity as a whole, Barlaam was not a Catholic, yet from very early on he became the embodiment of the Latin Church in the eyes of Orthodoxy. This can be explained first of all by the fact that he could not accept the teaching on uncreated energies, and so at this point his position bears resemblance to the Catholic one after all. Indeed, the doctrine on uncreated energies has not ceased to be a major challenge for Catholic theology, as much as it cares to deal with it. In case it can be understood as the manifestation of divine grace, it can be accepted and integrated, but this does not fully correspond with the Palamite position. Should we regard these energies as elements pertaining to the divine essence, they will appear to be incompatible with trinitology based on divine essence. ${ }^{20}$ On the other hand, this provides an answer for Orthodoxy to its challenge of how to maintain both absolute apophatism relating to divine immanence and the genuineness of God-man relationship at the same time: the Father makes use of His energies to act in the world through the Son and in the Holy Spirit without man gaining a firsthand insight into God's inner life, on a salvation historical basis. ${ }^{21}$

The dispute between Gregory and Barlaam, aiming predominantly at the authority of Mount Athos, became decisive for Orthodox-Catholic

\footnotetext{
${ }^{19}$ Norman Russel, The Doctrine of Deification in the Greek Patristic Tradition (Oxford: Oxford University Press, 2004), 304-9.

${ }^{20}$ Congar interprets energies as activity - in this way, he can integrate the Palamite perspective in his ecumenical approach. Yves Congar, Credo nello Spirito Santo, trans. Pietro Crespi (Brescia: Queriniana, 1998), 505-6.

${ }^{21}$ Gregory Palamas, The Triads, trans. Nicholas Gendle (Mahwah: Paulist Press, 1983), 88.
} 
relations. Barlaam's negative position and his late Catholicization reinforced the Greek belief that he was an exponent of the papacy. Gregory of Palamas's political and theological canonization was a natural consequence of this viewpoint: he is the defender of Orthodoxy and Byzantine traditions. This image became increasingly stronger in the Orthodox cultural context throughout the centuries to come and paved the way for the failure of the subsequent negotiations for unity. ${ }^{22}$ In this regard, it was the Council of Ferrara-Florence where opportunity most presented itself - what is more, a great many Catholic theologians erroneously think that this was the momentum when all material disagreements were resolved between Orthodoxy and the Catholic Church. This view is misguided as it disregards the fact that although the vast majority of the Orthodox representatives attending the Council did sign the documents of unity, it has never been ratified in the Byzantine successor states. Mark of Ephesus was the actual representative of the Orthodox standpoint at the Council, who showed willingness to agree on almost every aspect, but he could not accept that the phrase "through the Son" included both the Orthodox and the Catholic viewpoint on the procession of the Holy Spirit. As a defender of the Palamite tradition, the Filioque was a watershed issue for Mark, prompting his refusal to accept the Council's resolutions. His standpoint would later become the universal Orthodox position. ${ }^{23}$ Although it started out successfully, the Council of Florence ended in failure, no matter what many Catholic theologians think of it, given that the main objective, i.e., restoring unity, did not come to fruition. The basis of misinterpretation is that political pressure as the driving force of the Orthodox theologians' participation in the Council was a completely ignored fact: entering the final days of its existence, the Byzantine Empire was hoping for military support against the Ottoman attacks. Despite the Eastern willingness to compromise, the Western support never arrived, which once again confirmed to Orthodoxy that it could not count on help from the Catholic West, who had no other intention than forcing papal authority upon them at all costs. ${ }^{24}$ All of this came as a reassurance that Gregory Palamas was right to act in the defence of Orthodoxy

\footnotetext{
${ }^{22}$ Some Catholic theologians contend that in the case that Florence was a failure, it was the Orthodoxy's fault only. Christiaan Kappes, "A Latin Defense of Mark of Ephesus at the Council of Ferrara-Florence (1438-1439)," The Greek Orthodox Theological Review 59, no. 1-4 (Spring-Winter 2014): 161-4.

${ }^{23}$ Lossky, Théologie Dogmatique, 57-59.

${ }^{24}$ According to Popović, this unfaithful attitude of the Catholics proves that they turned away from the Holy Spirit. Iustin Popovici, Biserica și Statul. Adevărul despre Biserica Sârbă in Yugoslavia (Apologeticum, 2006), 20.
} 
against Barlaam, so all his teachings should be part of the Orthodox identity. In the year 1453, the political significance of Orthodoxy ceased to exist for a long period of time, and during the Ottoman rule, religious, ethnic, political, and cultural identity was preserved once again by the monasticism that completely embraced Palamism, along with its anti-Western characteristics. ${ }^{25}$

By the time the final day of the Byzantine Empire arrived, the change of identity had already taken place in its society, which would later contribute to the almost intact preservation of the Balkan peoples' ethnic-cultural identity in defiance of the long-lasting Ottoman rule. The key to survival lay in those symbolic Orthodox elements in consideration of which political power could be distinguished from cultural identity. Palamas was such a symbol as early as the fifteenth century and retained this status even after the end of the Ottoman rule, wherefore it is safe to claim that the Late Middle Ages made a decisive contribution to the formation of Orthodox identity.

\section{The Role of Palamism in the Present-Day Filioque Controversy}

It is the field of political identity for which late mediaeval theological-cultural changes had the most compelling implications in the twentieth century, which calls for a present-day reanalysis and reassessment of the significant role played by the mediaeval period. Without engaging in a lengthy historical review, it is worth mentioning that this process was launched in the nineteenth century, when the Balkan peoples were liberated from the Ottoman rule and Russia joined the ranks of the great powers and emerged as the defender of Orthodox peoples. However, it was not until the twentieth century that the renaissance of late mediaeval Palamism began among the Western Russian theologians living in diaspora, when the Sophia theory represented

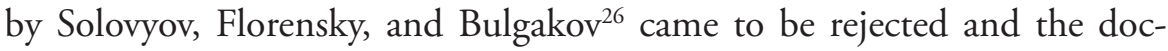
trine of uncreated energies was revived instead, thanks to Lossky's pioneering work. Its social background can be outlined as follows: Russian theologians living in the Western cultural context were seeking ways of preserving identity and would go back to symbols defending Orthodoxy in the Middle Ages.

\footnotetext{
${ }^{25}$ Part of the Greek clergy and monks has an anti-Catholic attitude even today; at the election of Pope Francis, they wrote an open letter calling the Catholic Church heretical because of Filioque, primacy, and other issues. Metropolitan Seraphim - Metropolitan Andrew, $A$ Letter to Pope Francis concerning His Past, the Abysmal State of Papism, and a Plea to Return to Holy Orthodoxy, see: http://orthodoxinfo.com/ecumenism/epistle-to-pope-francis.pdf, accessed June 28, 2021.

${ }^{26}$ Sergei O. Prokofieff, The Heavenly Sophia and the Being of Antroposofia (Forest Row: Temple Lodge, 2006).
} 
Interest in Photios had also grown, but the heritage of the ninth century patriarch was too controversial even for most of the Orthodox theologians. ${ }^{27}$

As a result of emigration, discussions resumed on the OrthodoxCatholic theological points of contention and, under some political pressure, they managed to bring the positions closer together, although these were mostly individual and not ecclesiastical initiatives. The increasing convergence of positions raised the question as to what would preserve Orthodox identity in the event of a potential unification. The answer provided by Lossky and some others was Palamism, which, however, implies the radical rejection of the Filioque clause: it is the Orthodox party who rejects the Catholic position on the procession of the Holy Spirit. ${ }^{28}$ This reductionist position did not receive an overwhelming response in the world of Catholic theology, but it launched the process of identity interpretation in the Orthodox literature, particularly in Greek and Romanian theology and social theory. In both of these cases, a key element leading up to this process was the work of Serbian theologians Nikolaj Velimirović and Justin Popović in the first half of the twentieth century. They regarded Serbian people as a chosen nation who preserved Orthodox tradition amongst the Muslim Turkish, the imperialist (and later communist) Russian, and the individualist Western cultural environments. ${ }^{29}$ The foundation of this mission derives from the preservation of Saint Sava's mediaeval heritage. This means that Velimirović and Popović clearly turn back to mediaeval times when defining present-day religious and political identity, which was a novel turn in that foundations had been previously sought from the Church Fathers.

The reinterpretation of the Middle Ages followed a similar path in the works of Greek authors such as Romanides and Yannaras. Besides the fact that both of them reject the Filioque, classing it under the heading of heresy, the latter also expands on its sociocultural aspects. First of all, Yannaras redefines the concept of Hellenism, which for him is the Greek culture built on Orthodox, Byzantine traditions, and only within that can one speak of true Christianity. ${ }^{30}$ In his view, the significance of Palamism has a predominantly cultural and not theological content, treating it as the Greek response to the

\footnotetext{
${ }^{27}$ According to Meyendorff, the patriarch's preparedness was deficient. John Meyendorff, Byzantine Theology: Historical Trends and Doctrinal Themes (New York: Fordham University Press, 1987), 60.

${ }^{28}$ Lossky, Orthodox Theology, 47.

${ }^{29}$ Iustin Popovici, Credința Ortodoxă și viața în Hristos, trans. Paul Bălan (Galați: Buna Vestire, 2003), 13.

${ }^{30}$ Christos Yannaras, Orthodoxy and the West, trans. Peter Chamberas and Norman Russel (Brookline: Holy Cross Orthodox Press, 2006), 24.
} 
challenges of scholasticism, or Thomism. Putting forward theological arguments does not suffice to reject the Filioque, but one needs to demonstrate the Western cultural threat inherent in the doctrine, which carried the danger of assimilating Orthodox Christianity as a community of nations. As postulated by Yannaras, Demetrios Kydones translating Saint Thomas's work Summa Theologae in the fourteenth century was a frontal assault against Greek culture since egoism made its way into Greek mentality to the detriment of community values. Also, this is the most prominent feature of Western society, which can be traced back to the Filioque doctrine that compromises the communion of love existing between the divine persons and accentuates the individual's psychological uniqueness, as a result of which we can only speak about selfishness. In contrast, Palamism - as the Greek rebuttal of scholasticism mentions the collaboration of persons, which can be said not only of divine immanence but also of Orthodox people's mentality. ${ }^{31}$ Insofar as Greeks wish to endure as cultural creators, they must follow the path of Palamism.

The most powerful adaptation of Palamism can be found in Romanian theology, in the works of Dumitru Stăniloae in particular. It is worth paying attention to every detail, as we can gain an important insight into how late mediaeval theological-cultural processes are moulding present-day identity. In the post-World War I period, Romanian society was vitally concerned with the issues of national identity and the place of religion in national self-determination. The dispute existing between the Orthodox and the Greek Catholic intelligentsia served as the starting point, both parties demanding the right to shape national identity. ${ }^{32}$ It was in this context that Nae Ionescu formulated his proposition that caused quite a stir, stating that a Romanian is one who is Orthodox..$^{33}$ It should be made clear at the outset that this was a politically charged and not a religious statement, as here Orthodoxy does not denote a confession of faith but a feature pertaining to ethnos, such as the mother tongue. This proposition was further developed by Nichifor Crainic under the form of ethnocracy, where religion is given a more prominent role as the cohesive force ensuring the unity of corporatist society.

Dumitru Stăniloae makes use of Ionescu and Crainic's theory but endows it with a new meaning and also changes the order of priority: first of all, he makes a theological statement that subsidiarily has a socio-political message. Practically speaking, these are inseparable since for him society is

\footnotetext{
${ }^{31}$ Ibidem, 11.

32 Zoltán Tóth calls this phenomenon a "golden bridge" between the two Romanian denominations. Zoltán Tóth, "Az erdélyi román nacionalizmus kialakulása," in Deér József and Gáldi László, Magyarok és románok, vol. 2 (Budapest: Athenaeum, 1943), 98.

${ }^{33} \mathrm{Nae}$ Ionescu, Indreptar ortodox (Bucharest: Artemis), 88-93.
} 
the carrier of the image and likeness of God, as a result of which theology is not about God alone but offers a life model for the national community. ${ }^{34}$ In his rich oeuvre, Stăniloae looks into Christian heritage, and it is Palamism where he discovers the element that enables him to link Christianity with the national mission. Palamas is the guardian of local interests and the advocate of universal values at the same time; in his teaching, the inner conflict of Orthodoxy - existing between the local and the universal church - is resolved. Adopting Palamas in contemporary Romanian theology and social approach allows for Stăniloae to speak of the Orthodox Romanian nation's uniqueness and its universal mission at the same time. ${ }^{35} \mathrm{~A}$ prerequisite for this is ensuring internal unity, which is, however, disrupted by the presence of the Greek Catholic Church. Therefore, Catholicism not only poses a threat to general Orthodoxy but also presents a major challenge in ethnic as well as ecclesiastical terms, which makes it crucial to demonstrate that in no way can it be appropriate for the nation as a whole. Hereby, I do not wish to touch upon Stăniloae's protracted fight carried on against the Greek Catholic Church, my aim being the mere presentation of the theoretical foundations. Whenever Stăniloae makes mention of society and nation, he always takes trinitology as a starting point.

Undoubtedly, Stăniloae's trinitology is nourished by Palamism although the influence of the Cappadocian Fathers and of Saint Augustus is also well traceable. Trinity is a communion of love, wherein the Father continuously turns towards the Son, who in turn continually responds to it. The communion of love of the Father and the Son is realized in the Holy Spirit through the Father's never-ceasing act of gifting. The Son's turning towards the Father is not realized in the origination of the Holy Spirit but in the acceptance of the Father's gift, in fulfilling the mission entrusted to Him by the Father. The divine immanent dynamism of love is not closing on itself but pours out into the created world through the uncreated energies. The source of these energies is again the Father, who gives them to the world through the Son and in the Holy Spirit. ${ }^{36}$ These energies sustain the world and, through theosis, connect man into the divine communion of love. The Filioque doctrine breaks this unity of love: the Holy Spirit's procession from the Son would imply that it denies the monarchy of the Father and sets itself

\footnotetext{
${ }^{34}$ Dumitru Stăniloae, “Scurtă interpretare teologică a naţiunii," in Ortodoxie și românism, (Sibiu: Editura Tipografiei Arhidiecezane, 1939).

${ }^{35}$ Idem, “De ce suntem ortodocși?”, Teologie și viața 57, no. 4-8 (1991): 15-27.

${ }^{36}$ Idem, Sfânta Treime sau la început a fost Iubirea (Bucharest: Editura Institutului Biblic și de Misiune Ortodoxă, 2012), 77.
} 
against Him, which would entail that the hypostases of the Father and the Son would join in the person of the Holy Spirit in such a way that the third person would dissolve therein (Stăniloae is rightly critical here of Heribert Mühlen's wir person concept ${ }^{37}$ ). The fundamental message of the doctrine of procession is unity in the community, which makes it eligible to serve as the basis for the representation of society.

For Stăniloae, the social model is based on the Trinity, wherein community, unity, and monarchy are all present. This image should emerge at all levels of society, from the family to the nation and the state. As per the example of the monarchy, the husband is the central figure of the family, and the wife and their children are present therein in relation to him. It is the man's duty to ensure the family's unity, to relegate individual interests to the background. Likewise, society functions on a Trinitarian basis: community interests always come before individual considerations. And if we are to take Catholic trinitology as a starting point, this social vision cannot come true because individualism will take over as a result of the Filioque. ${ }^{38}$ Adherence to Palamism means that society defines itself as a unified community in the image and likeness of God. Stăniloae takes the view that the Romanian nation is particularly capable of organizing on a Trinitarian basis, wherefore Orthodoxy is one of its inherent elements. This is where Florowsky's theory of pseudomorphism comes into play, making the claim that external effects generate in Orthodoxy as well as in the nation some configurations that are foreign to the society, i.e., accepting the Filioque would pervert the nature of the national-religious community. ${ }^{39}$

\section{Summary Account: The Role of Mediaeval Tradition in Present-Day Identity Formation}

The development and acceptance of Palamism presupposed the complex historical context that emerged in the thirteenth to fifteenth centuries, when Orthodoxy was confronted with internal division and external threat at the same time. This internal division can be observed in the tensions between hierarchy and monasticism, which has been in fact an ever-present aspect of Christianity under different forms and to varying degrees. Given that political power made every attempt to exploit this situation to its advantage, it was inevitable that controversies within the church would have a political di-

\footnotetext{
${ }^{37}$ Idem, "De ce suntem ortodocși?", 15-27.

${ }^{38}$ Idem, “Creștinism și tradiție în viața națională,” Luceafărul 1, no. 2 (1941): 1.

${ }^{39}$ George Florovsky, "The Ethos of the Orthodox Church," The Ecumenical Review 12, no.

2 (1960): 191.
} 
mension as well. ${ }^{40}$ Monasticism emerged as the more effective segment in the case of Orthodoxy, securing at the same time the preservation of Orthodox identity during Ottoman rule. It is to the great credit of the late mediaeval era that it developed the ecclesiastical-social forms that would subsequently give rise to modern nations. Therefore, it hardly comes as a surprise that even though secularization became a reality in a later period in the Balkan region as well, this did not imply doing away with religious forms. ${ }^{41}$

Today, Palamism should be primarily valued as a cultural force when talking about identity - as a "product" of theological development that can function as a cohesive and distinguishing feature in the long run. It acts as a unifying force within Orthodoxy, while it conserves the given community when exposed to external effects. ${ }^{42} \mathrm{~A}$ process called dogmatic identification comes to pass here: social, cultural, ethnic, or political self-determination takes place along a specific dogma. This time, the process is brought about by an identification dogma, the Filioque. Theological content is, in fact, only of secondary importance in this process, true significance being borne by the way various actors approach the doctrine. It seems reasonable to ask here to what extent late mediaeval Palamism corresponds with this aspect, as it has been established that both Palamas and Barlaam rejected the Filioque. But then Barlaam rejected the doctrine of uncreated energies as well, the very rationale used by Palamas to steer clear of the necessity of the Filioque when he was talking about knowing God or the God-man relationship. Rejecting Palamism, Barlaam excluded himself from the community of Orthodoxy, and so he is to be ultimately considered among the representatives of filioquist Catholicism. ${ }^{43}$ This too confirms that when a dogma becomes an element of identification, i.e., a symbol, its theological content gets relegated to the background.

The same process can be witnessed in a particular segment of twentieth century Orthodox theology, in the case of the neo-Palamites. They go back to mediaeval traditions, adopt symbolic elements that they can assign new meaning to, and then place their message in a complex religious-social framework. The Filioque is the manifestation of heterodox influences against which Orthodox ethnicity must be defended. This becomes a basic tenet,

\footnotetext{
${ }^{40}$ Brubaker, Religion and Nationalism, 8.

${ }^{41}$ According to Hobsbawm, religion survived secularization in regions where interethnic tensions were present. Eric J. Hobsbawm, Nations and Nationalism since 1780. Programme, Myth, Reality (Cambridge: Cambridge University Press, 1992), 69-70.

${ }^{42}$ Brubaker, Religion and Nationalism, 11.

${ }^{43}$ John Romanides, "Notes on the Palamite Controversy and Related Topics," The Greek Orthodox Theological Review 6 (1960-1961): 186-205.
} 
and it would be brought down to ashes should it be eliminated from social theory, which is consequently of dogmatic nature: it rests upon theses that are generally considered to be true. The negative position on the Filioque must be regarded as correct because Orthodox identity cannot change: it must carry the same meaning as it did in the fourteenth and fifteenth centuries. ${ }^{44}$ A reinterpretation of the mediaeval era is not about criticizing or rejecting it but making it up to date.

In summary, we can state that the Middle Ages gave birth to those basic ideological tenets that added to the dimension of the Filioque controversy, thus "forcing" the dialogue developed around the doctrine at issue to transcend the ecclesiastical context. Certainly, this becomes meaningful only if both Orthodox and Catholic concepts are also examined in a social-political-cultural context, and not merely as ecclesiastical designations. Hence, it can be claimed that present-day identity has its roots in the Middle Ages.

My claim that the Filioque is an identification dogma, i.e., that based on the approach to it one can distinguish an Orthodox from a heterodox, is not a criticism aimed at Orthodoxy, but, on the contrary, an attempt to understand it. Catholic theology is the main addressee here, which treats the Filioque strictly as a question pertaining to Trinitology and takes no notice of the complex social impact it generates. Recognizing that the Filioque acts as an identification dogma and that a dogmatic identification is developed as a result poses a major challenge to ecumenical efforts. It is not enough to interpret a doctrine by itself, but we must assess its relevance for the other party concerned. I tend to believe that the dialogue centred around the Filioque has now ground to a halt, and its resumption presupposes the Catholic (and Protestant) party's endeavour to achieve an understanding of the complex nature of Orthodoxy. For this to happen, Catholic theology, too, must accomplish the task of revisiting the role played by the mediaeval period in present-day identity formation.

\footnotetext{
${ }^{44}$ According to Bulgakov, this restrictive view of Filioque as a dogma (regardless of its content) must be avoided for the sake of Christianity. Because of endless controversy, the Filioque became a dogma without power. Sergius Bulgakov, The Comforter, trans. Boris Jakim (Cambridge: William B. Eerdmans, 2004), 130-31.
} 